\title{
Diurnal, weekly, seasonal, and spatial variabilities in carbon dioxide flux in different urban landscapes in Sakai, Japan
}

\author{
Masahito Ueyama and Tomoya Ando \\ Graduate School of Life and Environmental Sciences, Osaka Prefecture University, 1-1, Gakuen-cho, Naka-ku, Sakai, \\ Osaka, 599-8531, Japan \\ Correspondence to: Masahito Ueyama (miyabi-flux@muh.biglobe.ne.jp)
}

Received: 18 April 2016 - Published in Atmos. Chem. Phys. Discuss.: 21 June 2016

Revised: 8 November 2016 - Accepted: 8 November 2016 - Published: 25 November 2016

\begin{abstract}
To evaluate $\mathrm{CO}_{2}$ emissions in urban areas and their temporal and spatial variability, continuous measurements of $\mathrm{CO}_{2}$ fluxes were conducted using the eddy covariance method at three locations in Sakai, Osaka, Japan. Based on the flux footprint at the measurement sites, $\mathrm{CO}_{2}$ fluxes from the three sites were partitioned into five datasets representing a dense urban center, a moderately urban area, a suburb, an urban park, and a rural area. A distinct biological uptake of $\mathrm{CO}_{2}$ was observed in the suburb, urban park, and rural areas in the daytime, whereas high emissions were observed in the dense and moderate urban areas in the daytime. Weekday $\mathrm{CO}_{2}$ emissions in the dense urban center and suburban area were approximately $50 \%$ greater than emissions during weekends and holidays, but the other landscapes did not exhibit a clear weekly cycle. Seasonal variations in the urban park, rural area, and suburban area were influenced by photosynthetic uptake, exhibiting the lowest daily emissions or even uptake during the summer months. In contrast, the dense and moderately urban areas emitted $\mathrm{CO}_{2}$ in all seasons. $\mathrm{CO}_{2}$ emissions in the urban areas were high in the winter and summer months, and they significantly increased with the increase in air temperature in the summer and the decrease in air temperature in the winter. Irrespective of the land cover type, all urban landscapes measured in this study acted as net annual $\mathrm{CO}_{2}$ sources, with emissions ranging from 0.5 to $4.9 \mathrm{~kg} \mathrm{C} \mathrm{m}^{-2} \mathrm{yr}^{-1}$. The magnitude of the annual $\mathrm{CO}_{2}$ emissions was negatively correlated with the green fraction; areas with a smaller green fraction had higher annual $\mathrm{CO}_{2}$ emissions. Upscaled flux estimated based on the green fraction indicated that the emissions for the entire city were $3.3 \mathrm{~kg} \mathrm{C} \mathrm{m}^{-2} \mathrm{yr}^{-1}$, which is equivalent to $0.5 \mathrm{Tg} \mathrm{C} \mathrm{yr}^{-1}$ or $1.8 \mathrm{MtCO}_{2} \mathrm{yr}^{-1}$, based on the area of the city $\left(149.81 \mathrm{~km}^{2}\right)$.
\end{abstract}

A network of eddy covariance measurements is useful for characterizing the spatial and temporal variations in net $\mathrm{CO}_{2}$ fluxes from urban areas. Multiple methods would be required to evaluate the rationale behind the fluxes and overcome the limitations in the future.

\section{Introduction}

Cities emit a considerable amount of carbon dioxide $\left(\mathrm{CO}_{2}\right)$ that is associated with human activities into the atmosphere (Canadell et al., 2007). Urban areas account for only a small percentage of the earth's land surface but emit 30-50\% of total anthropogenic $\mathrm{CO}_{2}$ (Mills, 2007; Satterthwaite, 2008), and thus cities are important sources of the global $\mathrm{CO}_{2}$ emissions. The $\mathrm{CO}_{2}$ emissions among global cities are highly heterogeneous (Mills, 2007; Nordbo et al., 2012), and the temporal variability is high (Velasco and Roth, 2010). To evaluate the spatiotemporal variabilities in $\mathrm{CO}_{2}$ emissions for global cities, studies using multiple methods, such as measurements (Velasco and Roth, 2010) and emission inventories (Oda and Maksyutov, 2011), are currently being conducted.

Global $\mathrm{CO}_{2}$ emissions have often been estimated using emission inventories based on point source databases, statistics for national and regional $\mathrm{CO}_{2}$ emissions, and satellite remote sensing (Oda and Maksyutov, 2011). The major challenge for estimating global $\mathrm{CO}_{2}$ emissions is to understand the spatiotemporal dynamics of $\mathrm{CO}_{2}$ emissions in various cities. Because emissions data are used in top-down estimates of the global $\mathrm{CO}_{2}$ budget (Peters et al., 2007; Schimel et al., 2001), a better estimate of $\mathrm{CO}_{2}$ emissions from cities 
will improve our understanding of the global carbon cycle, including terrestrial and ocean fluxes.

To evaluate $\mathrm{CO}_{2}$ emissions in cities and their temporal and spatial variabilities, continuous measurements of $\mathrm{CO}_{2}$ fluxes have been conducted using the eddy covariance method in various urban landscapes in several cities, including dense urban built-up areas (Gioli et al., 2012; Grimmond et al., 2002, 2004; Kotthaus and Grimmond, 2012; Nimitz et al., 2002; Pawlak et al., 2011; Velasco et al., 2005), suburban areas (Bergeron and Strachan, 2011; Coutts et al., 2007; Crawford et al., 2011; Hirano et al., 2015; Moriwaki et al., 2006; Ward et al., 2013), urban parks (Kordowski and Kuttler, 2010), and urban forests (Awal et al., 2010). These results have indicated that cities emits a considerable amount of $\mathrm{CO}_{2}$ into the atmosphere from human activities, such as vehicle traffic and household heating in the wintertime. Even in urban parks, $\mathrm{CO}_{2}$ was emitted to the atmosphere due to human activities (Kordowski and Kuttler, 2010). The magnitude of $\mathrm{CO}_{2}$ emissions and its temporal variability depended on the city, associated with the type of human activities under different climate conditions (Järvi et al., 2012; Moriwaki et al., 2006; Velasco et al., 2016; Ward et al., 2013, 2015), and the role of urban vegetation (Awal et al., 2010; Kordowski and Kuttler, 2010; Peters and McFadeen, 2012; Ward et al., 2015), showing considerable heterogeneities.

Multi-site eddy covariance towers were used to synthesize the data and showed that green fraction was the index that explained the spatial variability in annual $\mathrm{CO}_{2}$ emissions (Nordbo et al., 2012; Velasco and Roth, 2010; Ward et al., 2015), because the green fraction has many possible factors that determine $\mathrm{CO}_{2}$ emissions: a greater green fraction correlates with lesser road and population densities (Nordbo et al., 2012). Upscaling using the green fraction can provide a highresolution map of direct $\mathrm{CO}_{2}$ emissions from cities. Previous studies have examined the relationship between annual $\mathrm{CO}_{2}$ emissions and the green fraction at a global scale (Nordbo et al., 2012; Velasco and Roth, 2010; Ward et al., 2015). It is unclear whether upscaling of $\mathrm{CO}_{2}$ emissions is possible within a city, because multi-site eddy covariance measurements within a city are often unavailable.

In this study, we present diurnal, weekly, seasonal, and spatial variabilities in the $\mathrm{CO}_{2}$ fluxes continuously measured at three different locations within $5 \mathrm{~km}$ of each other in Sakai, Osaka, Japan. Considering flux footprint, the data represent five urban landscapes, including a dense urban center, a moderately urban area, a suburb, a rural area, and an urban park. Regardless of the landscape type, all landscapes emitted considerable $\mathrm{CO}_{2}$ annually with different temporal metabolisms, providing a useful overview of anthropogenic $\mathrm{CO}_{2}$ emissions.
Table 1. Land cover fraction within the daytime flux footprint. Land cover classification was conducted using the Digital Map 5000 for the Kinki region in 2008 by the Geospatial Information Authority of Japan, and the green space fraction was based on a green census by the government of Sakai City. Because the land cover classification and green space are different data sources, the sum of each fraction often exceeds $100 \%$. The daytime flux footprint was calculated using the analytical footprint model (Kormann and Meixner, 2000), and median values in 2015 were classified for 16 directions (Fig. 1).

\begin{tabular}{lrrrrr}
\hline & $\begin{array}{rrrr}\text { SAC } \\
\text { west } \\
\%\end{array}$ & $\begin{array}{r}\text { SAC } \\
\text { east } \\
\%\end{array}$ & $\begin{array}{r}\text { OPU } \\
\%\end{array}$ & $\begin{array}{r}\text { IZM } \\
\text { park } \\
\%\end{array}$ & $\begin{array}{r}\text { IZM } \\
\text { rural } \\
\%\end{array}$ \\
\hline Residence & 27 & 9 & 9 & 1 & 15 \\
$\begin{array}{l}\text { Commercial, industrial, } \\
\text { and public office }\end{array}$ & 34 & 38 & 69 & 6 & 15 \\
Road & & & & & \\
Green space & 27 & 29 & 10 & 3 & 6 \\
\hline
\end{tabular}

\section{Materials and methods}

\subsection{Study sites}

Sakai is the second largest city in Osaka Prefecture, located in western Japan. The population was approximately 842000 in 2015. Because the city is located on the eastern shore of Osaka Bay, sea-breeze circulation is evident throughout the year, except when seasonal winds are not strong. The area is on a uniformly flat plane; the north-south and the eastwest slopes are 0.0030 and $0.0024^{\circ}$, respectively. The climate of Sakai is temperate; the mean annual air temperature is $15.9^{\circ} \mathrm{C}$, the maximum monthly mean air temperature was $28.0^{\circ} \mathrm{C}$ in August, the minimum monthly mean air temperature was $5.2^{\circ} \mathrm{C}$ in January, and the mean annual precipitation was $1187 \mathrm{~mm} \mathrm{yr}^{-1}$ between 1981 and 2010 according to the Japanese Meteorological Agency.

The Sakai city center (SAC) site (Fig. 1; Table 1) is located on a tower at the top of a city office building $\left(34^{\circ} 34^{\prime} 25^{\prime \prime} \mathrm{N}\right.$, $\left.135^{\circ} 28^{\prime} 59^{\prime \prime} \mathrm{E}\right)$. The population density around the city center is approximately $12150 \mathrm{~km}^{-2}$, based on the Japanese Government Statistics. The area is a densely built-up urban area with a mean building height of $10.7 \pm 3.1 \mathrm{~m}$. Because the distributions of building heights were highly skewed toward low-height buildings, the mean building height greater than 20 was $36 \mathrm{~m}$, which occupied $33 \%$ of the total building area. Many arterial roads and two highways with heavy traffic are present within the flux footprint. Because industrial and commercial areas are located in the western and northern parts of the city, those areas are expected to show higher rates of human activity than locations where residential areas are dominant.

The Oizumi Ryokuchi urban park (IZM) site (Fig. 1; Table 1$)$ is located at the northern end of the city $\left(34^{\circ} 33^{\prime} 48^{\prime \prime} \mathrm{N}\right.$, 


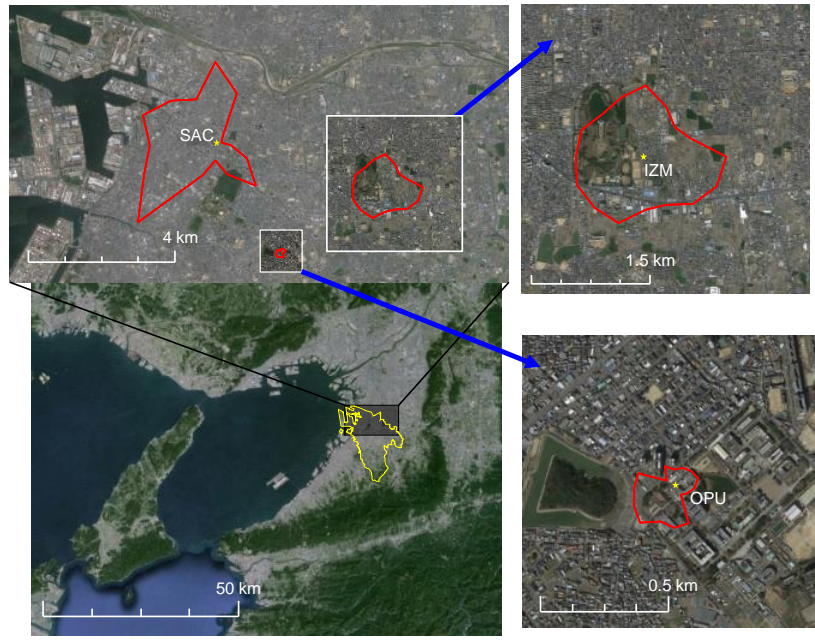

Figure 1. Aerial photograph by Google Earth showing the study area, where the $80 \%$ flux footprint in daytime is shown with red lines. The boundary of Sakai City is shown as a yellow contour.

$135^{\circ} 32^{\prime} 1^{\prime \prime} \mathrm{E}$ ) and was established in 1972 . The measurements were conducted at a tower located at the eastern edge of the park. Because of the consistent presence of a sea breeze, the tower is mostly located downwind of the park during the daytime. The land cover of the park consists of $51 \%$ trees, $15 \%$ grassland, and $34 \%$ other, such as ponds, buildings, pavement, and bare ground. No vehicle traffic was allowed in the park except for parking. Measurements using a plant canopy analyzer (LAI-2000, LI-COR, Lincoln, Nebraska, USA) showed that the leaf area index of trees ranged from 3.2 to $5.7 \mathrm{~m}^{2} \mathrm{~m}^{-2}$ with a mean of $4.3 \mathrm{~m}^{2} \mathrm{~m}^{-2}$ in the summer months. The mean and maximum tree heights were estimated as $12.3 \pm 4.1$ and $21 \mathrm{~m}$, respectively, using a digital surface model by Google Earth. The area surrounding the IZM is a mixed landscape of residential areas and agricultural fields and is characterized as a rural area (Table 1). The population density of surrounding residences surrounding the IZM is approximately $7940 \mathrm{~km}^{-2}$, based on the Japanese Government Statistics.

The Osaka Prefecture University (OPU) site (Fig. 1; Table 1) is located at the western edge of Osaka Prefecture University ( $\left.34^{\circ} 32^{\prime} 50^{\prime \prime} \mathrm{N}, 135^{\circ} 30^{\prime} 10^{\prime \prime} \mathrm{E}\right)$. Because the measurements were conducted on the roof of a building, the flux footprint represents only a small suburban area. The western part of the site contains a protected forest on a kofun (an ancient burial mound), Mozu Kofungun. The area is characterized as a suburb, consisting of a university, a residential area, small streets, a graveyard, and trees. The mean and maximum tree heights were $13.1 \pm 2.9$ and $19 \mathrm{~m}$, respectively, and the mean and maximum building heights are $9.1 \pm 2.9$ and $15 \mathrm{~m}$, respectively.

\subsection{Observations}

We measured $\mathrm{CO}_{2}$ fluxes using the eddy covariance method at the three sites. For SAC, a sonic anemometer (SAT550, Sonic Corp., Tokyo, Japan) and an open-path infrared gas analyzer (LI-7500, LI-COR) were installed on a $16 \mathrm{~m}$ tower located at the top of the city office building $(111 \mathrm{~m}$ above the ground) at the end of November 2009. For IZM, a sonic anemometer (CSAT3, Campbell Scientific Inc., Logan, Utah, USA) and an open-path infrared gas analyzer (EC150, Campbell Scientific Inc.) were installed $30 \mathrm{~m}$ above the ground on a tower at the end of January 2015. For OPU, sonic anemometers and several infrared gas analyzers were installed on a $2 \mathrm{~m}$ mast above the rooftop at the edge of the building (16.2 $\mathrm{m}$ above the ground) in November 2014. Turbulent fluctuations were recorded at $10 \mathrm{~Hz}$ using a data $\log$ ger (8421, Hioki, Japan) for SAC and data loggers (CR1000, Campbell Scientific Inc.) for IZM and OPU.

For the OPU site, eddy covariance systems were periodically changed. A sonic anemometer (DA600, Sonic Corp.) was in place from November 2014 to March 2015 and again in November 2015. A different sonic anemometer (model 81000, R. M. Young, Traverse, Michigan, USA) was in place from March to April 2015, and a third type of sonic anemometer (Windmaster, Gill Instruments, Lymington, UK) was in place in April 2015. The eddy covariance system was initially a closed-path system using a gas analyzer (LI-6262, LI-COR), until March 2015, and was then changed to an open-path system using an open-path infrared gas analyzer (LI-7500, LI-COR). Another eddy covariance system using a sonic anemometer (DA600, Sonic Corp.) and an open-path infrared gas analyzer (LI-7500, LICOR) was installed on a different edge of the building in November 2015. This additional measurement system increased data acquisition, because we eliminated the data coming from the roof. Consequently, $\mathrm{CO}_{2}$ fluxes were calculated based on the different systems with relevant corrections. We confirmed that there was no significant difference between open-path and closed-path systems through an intercomparison $\left(\mathrm{RMSE}=2.18 \mu \mathrm{mol} \mathrm{m}^{-2} \mathrm{~s}^{-1} ; F_{\mathrm{open}}=1.00\right.$. $F_{\text {closed }}-0.03 \mu \mathrm{mol} \mathrm{m}^{-2} \mathrm{~s}^{-1} ; R^{2}=0.84 ; F_{\text {open }}$ and $F_{\text {closed }}$ represent $\mathrm{CO}_{2}$ fluxes by the open and closed paths, respectively), but these flux measurements have higher uncertainties than those from the other sites.

Meteorological and environmental variables were measured at each site. The air temperature, relative humidity, and incoming solar radiation were measured at the three sites. Rainfall, atmospheric pressure, incoming longwave radiation, and ground heat fluxes at the top of the building were measured at OPU. The leaf area index was manually measured approximately once a month using a plant canopy analyzer (LAI-2000, LI-COR) at 10 forested sectors in IZM.

The gas analyzers were periodically calibrated. Because the open-path gas analyzer for SAC was installed at a location to which gas cylinders could not be carried easily, 
we calibrated the analyzer by comparing the signals of $\mathrm{CO}_{2}$ and $\mathrm{H}_{2} \mathrm{O}$ densities from a closed-path analyzer (LI-840, LICOR), whose inlet was located near the open-path analyzer. The closed-path analyzer was calibrated every 4 months using a known $\mathrm{CO}_{2}$ gas, zero $\mathrm{CO}_{2}$ gas, and a dew point generator (LI-610, LI-COR). For OPU, the gas analyzers were calibrated three times in 2015 using the gases and the dew point generator. For IZM, maintenance was regulated, and thus the analyzer was only calibrated at the start and end of the measurements.

\subsection{Data analysis}

In this study, we used 1-year eddy covariance data measured in 2015 at SAC and OPU and the period from February 2015 to January 2016 at IZM. Turbulent fluxes were calculated with the eddy covariance method using the Flux Calculator program (Ueyama et al., 2012). Before the halfhourly covariance of vertical wind velocity and scalar quantities were calculated, spike data were removed from the raw data. No trend removal was applied. The artificial fluctuations of sonic air temperature associated with water vapor were corrected. The vertical wind velocity was coordinated as the mean vertical wind velocity was equal to zero using the double-rotation method. The angle-of-attack errors for the Gill Instruments and R. M. Young anemometers were corrected based on Nakai and Shimoyama (2012) and Kochendorfer et al. (2012), respectively. The high-frequency loss for line averaging and sensor separation was corrected using theoretical transfer functions for the open-path systems (Massman, 2000) and empirical transfer functions for the closedpath system (Moore, 1986). Air density fluctuations were corrected based on Webb et al. (1980).

Filtering of the nighttime data using the friction velocity $\left(u_{*}\right)$ threshold was not applied in this study. This was because (1) no clear threshold was obtained in nighttime data, (2) data coverage at night was small due to the limited flux footprint, and (3) sensible heat fluxes in the summer months often showed positive values even at night, except for IZM. Our handling of nighttime data was the same as in previous studies in urban areas (e.g., Liu et al., 2012), but a potential underestimate of nighttime fluxes may have occurred. The storage term was added to the turbulent fluxes for the vegetative site (IZM), whereas storage was not considered for urban sites (SAC and OPU). The storage term for IZM was estimated based on $\mathrm{CO}_{2}$ concentrations at the height of the eddy covariance measurements.

Flux data were selected for each landscape after a quality test and footprint analysis. First, we applied the quality test to remove half-hourly flux data that included noise based on a criterion (Appendix B1 in Ueyama et al., 2012). A stationary test, an integral turbulence test, and a higher-moment test were applied, because flow statistics did not strongly differ with ideal surfaces (Kaimal and Finnigan, 1994); $\sigma_{w} / u_{*}$ at neutral conditions was 1.3 for SAC, 1.5 for OPU, and 1.3 for
IZM; and $\sigma_{u} / u_{*}$ at neutral conditions was 2.6 for SAC, 2.6 for OPU, and 3.2 for IZM, where $\sigma_{w}$ and $\sigma_{u}$ are the standard deviation of vertical and horizontal wind velocities, respectively. Half-hourly data were subdivided into $5 \mathrm{~min}$, and then the covariance was calculated for the $5 \mathrm{~min}$ data. If the difference between the mean of the covariance for the subdivided classes and half-hourly covariance was greater than $40 \%$ of the half-hourly covariance, the data were rejected as instationary (Foken and Wichura, 1996). We rejected the data when the turbulent intensity was greater than $50 \%$ for IZM and $200 \%$ for SAC and OPU of the intensities predicted by the similarity theory. According to the high-moment test (Vickers and Mahrt, 1997), we removed data when the absolute value of skewness was greater than 3.6 or when the value of kurtosis was greater than 14.4. The fluxes, measured when winds came from the tower directions, were also removed. For OPU, the fluxes, measured when winds came from the directions of the building, were also removed. For SAC, based on a footprint model (Kormann and Meixner, 2000), we rejected data when the source area contributing $80 \%$ of the flux footprint contained sea and mountains. Similarly, for IZM, we rejected flux data when the source area contributing $50 \%$ of the flux footprint exceeded the boundary of the urban park. The displacement height was estimated based on MacDonald et al. (1998) for SAC, whereas those heights for the other sites were estimated at 0.7 times of the mean building or tree heights.

Depending on the wind direction, flux data at IZM and SAC were divided into two data series. For IZM, the flux data from the west represented the urban park, whereas data from other directions represented the rural area consisting of mixed residential and agricultural areas (Fig. 1). For SAC, flux data from the west represented the densely built-up urban center, whereas data from other directions represented the moderate urban to residential area (Fig. 1). Here, we defined the moderate urban area having a green fraction of $27 \%$, which was double that of the dense urban built-up area (Table 1). Consequently, we formed five flux datasets from measurements at the three sites in 2015 for SAC and OPU and in the period from February 2015 to January 2016 in IZM: a dense urban center (west SAC), a moderately urban area (east SAC), a suburb (OPU), an urban park (west IZM), and a rural area (east IZM). Data coverage was $11 \%$ in west SAC, $21 \%$ in east SAC, $31 \%$ in OPU, $16 \%$ in west IZM, and $13 \%$ in west IZM.

Partitioning $\mathrm{CO}_{2}$ fluxes into gross photosynthetic and respiratory fluxes was conducted only for the west and east IZM and OPU datasets because the apparent daytime uptake was measured. The flux partitioning was conducted using the Flux Analysis Tool program (Ueyama et al., 2012). First, the relationship between nighttime $\mathrm{CO}_{2}$ fluxes and air temperature was established based on a model (Lloyd and Taylor, 1994). The relationship was determined daily with a 49-day moving window. The gross photosynthetic flux was calculated as the difference between the estimated respiratory flux 
and the measured $\mathrm{CO}_{2}$ flux. Because the estimated respiratory fluxes consisted of biological fluxes and nighttime anthropogenic fluxes, it is important to note that the estimated gross photosynthetic fluxes did not truly represent gross primary productivity, which is often used in ecosystem studies (e.g., Baldocchi, 2014).

Gaps in the five datasets were filled using the Flux Analysis Tool program. First, small data gaps for periods of less than $2.0 \mathrm{~h}$ were filled by linear interpolation. Second, for the west and east IZM datasets, gaps were filled using a combination of a look-up table and nonlinear regression methods (Ueyama et al., 2012), an approach well established for use in natural ecosystems (Ueyama et al., 2013). For data gaps from the west and east SAC and OPU, mean diurnal variations were applied, in which a mean diurnal pattern was created daily using a 51-day moving window. Two mean diurnal patterns were created, one for weekdays and one for weekends and holidays according to the weekly cycle.

For evaluating vegetation activity in response to solar radiation $\left(R_{\mathrm{S}}\right), \mathrm{CO}_{2}$ fluxes $\left(F_{c}\right)$ for IZM and OPU were regressed for summer months using the following rectangular hyperbola:

$F_{c}=-\frac{P_{\max } b R_{\mathrm{s}}}{P_{\max }+b R_{\mathrm{s}}}+R_{\mathrm{d}}$

where $P_{\max }$ is the maximum photosynthetic rate, $b$ is the initial slope, and $R_{\mathrm{d}}$ is dark respiration.

\subsection{Upscaling using GIS data}

The annual $\mathrm{CO}_{2}$ flux was upscaled according to the relationship between annual fluxes and the green fraction. The green fraction was estimated using green census data developed by the government of Sakai City. The green census data were created using high-resolution aerial photographs from $\mathrm{Au}-$ gust 2001, which consisted of polygons of an approximately $5 \mathrm{~m}$ spatial resolution. Based on the high-resolution polygon data, the green fraction was evaluated at a $500 \mathrm{~m}$ spatial resolution. Because the green census data often classified water as green area, we masked the water area using a land cover data based on a geographical information system (GIS; Digital Map 5000 for the Kinki region in 2008 by the Geospatial Information Authority of Japan).

\section{Results}

\subsection{Meteorological characteristics}

The air temperature and vapor pressure deficit (VPD) showed clear seasonal variations (Fig. 2). The air temperature was lowest in January $\left(5.9^{\circ} \mathrm{C}\right)$ and highest in August $\left(28.2^{\circ} \mathrm{C}\right)$, based on a meteorological station of the Japanese Meteorological Agency. From late July to mid-August, the daily maximum air temperature was continuously higher than $30^{\circ} \mathrm{C}$
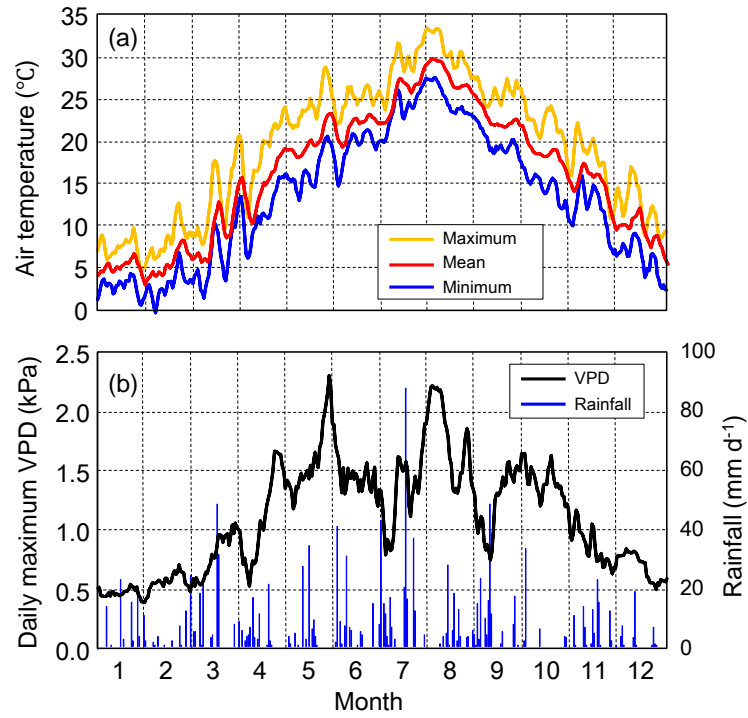

Figure 2. Seasonal variations in (a) daily mean, maximum, and minimum air temperatures and (b) daily maximum vapor pressure deficit (VPD) and daily total rainfall. Temperatures and VPD were measured at $111 \mathrm{~m}$ above the ground at the SAC site and rainfall was measured at the OPU site, during 2015. Temperatures and VPD are shown as a 7-day running mean.

(Fig. 2a). Even in the winter, the daily minimum air temperature often did not reach negative values. The daytime maximum VPD was high from late April to mid-October but showed a decline in a rainy season, called Baiu, from late June to mid-July, with the typhoon season starting from early September (Fig. 2b). The annual rainfall was $1324 \mathrm{~mm} \mathrm{yr}^{-1}$ in 2015

Due to a sea breeze, each site had distinct wind characteristics (Fig. 3). In SAC, winds mainly came from the northwestern and eastern sectors. Winds came from the western and northwestern sectors in OPU, and the winds came from the western to northern sectors and an eastern sector in IZM. These characteristics were consistent throughout the seasons (Fig. A1).

\subsection{Diurnal variations}

Diurnal variations at $\mathrm{SAC}$ showed greater $\mathrm{CO}_{2}$ emissions during the daytime than at night $(p<0.01)$ (Fig. 4). Daytime emissions were greater in the dense urban center (west SAC) than in the moderately urban area (east SAC) throughout the seasons $(p<0.01)$. Emissions from the urban areas were significantly higher in the daytime than in the nighttime in all seasons $(p<0.01)$. Such diurnal variations were similar to those for traffic counts measured by highway exits within the flux footprint (Fig. 4b). Note that the traffic counts at the exits peaked in the evening, whereas those at the entries could peaked in the morning (data not shown). Based on a comparison for diurnal cycles under different weather con- 


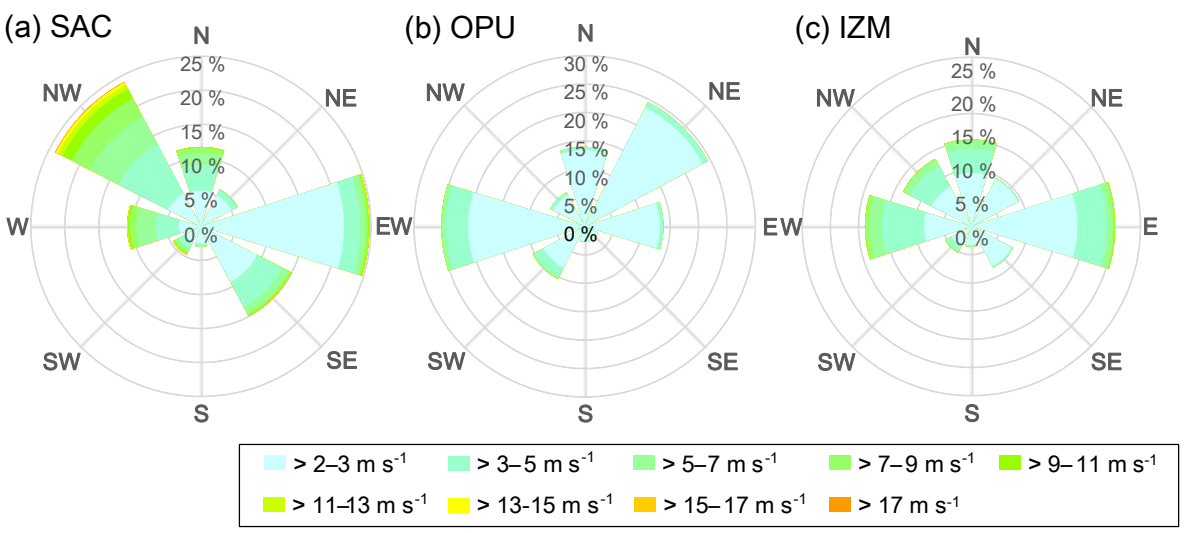

Figure 3. Relative wind frequency distributions at the three sites during the study period in 2015 . Data are binned in $45^{\circ}$ classes.

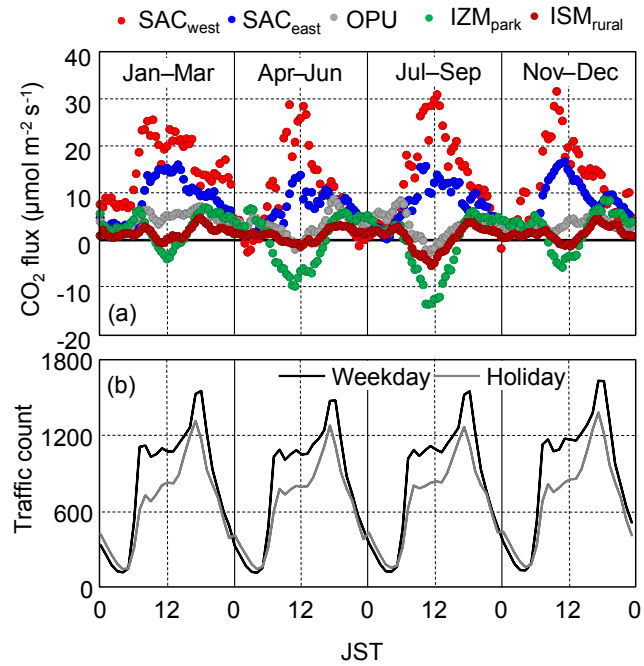

Figure 4. Mean diurnal variations in (a) $\mathrm{CO}_{2}$ fluxes and (b) traffic count at two highway exits within the flux footprint of SAC west. The diurnal patterns were created every consecutive 3 months in 2015. Because measurements at IZM began in February 2015, diurnal variations for IZM during the period from January to March were calculated based on data from February and March in 2015 and January in 2016.

ditions, $\mathrm{CO}_{2}$ emissions in the afternoon tended to be higher on sunny days than on rainy or cloudy days for both the west $(p<0.01)$ and east $(p=0.33)$ SAC (Fig. A2a, b). In contrast to $\mathrm{CO}_{2}$ fluxes, there was no significant difference in the traffic counts for sunny and rainy/cloudy days.

In contrast to $\mathrm{SAC}, \mathrm{CO}_{2}$ fluxes in OPU and IZM showed distinct daytime uptake especially in summer months (Fig. 4). The magnitude of the daytime uptake was stronger in the urban park than in the rural area. A daytime uptake was also observed at OPU in the summer months from April to August. For these three landscapes, the $\mathrm{CO}_{2}$ uptake increased with solar radiation (Fig. 5). According to the rectangular hyperbola regressed between $\mathrm{CO}_{2}$ fluxes and solar radi- ation, the rural area $\left(R^{2}=0.46\right)$ and urban park $\left(R^{2}=0.34\right)$ of IZM have a stronger light dependency than the suburb in OPU $\left(R^{2}=0.10\right)$. The high light dependency in the urban park and the rural area suggests that light was the major controlling factor in $\mathrm{CO}_{2}$ fluxes at the diurnal timescale. This was consistent with the smaller $\mathrm{CO}_{2}$ uptake on rainy or cloudy days than on sunny days in the rural area (Fig. A2e). For the urban park and OPU, the lack of a significant difference among weather conditions (Fig. A2c, d) suggests that $\mathrm{CO}_{2}$ fluxes were also influenced by other factors, such as spatial heterogeneity and temperature conditions. For example, sunny days were warmer in the daytime (approximately $2.5^{\circ} \mathrm{C}$ in the afternoon) and colder (approximately $1.1^{\circ} \mathrm{C}$ just before the sunrise) in the nighttime than rainy/cloudy days.

\subsection{Seasonal variations}

Different urban landscapes showed different seasonal variations in the $\mathrm{CO}_{2}$ flux (Fig. 6). Similar to the diurnal variations, distinct biological signals were observed at IZM in the urban park and rural area. The daily mean $\mathrm{CO}_{2}$ fluxes showed lower emissions with occasional negative values during summer months in both IZM sites. The suburban site of OPU generally showed $\mathrm{CO}_{2}$ emissions throughout the seasons, but the emissions rate tended to be lower in the spring than in other months. The SAC site showed high $\mathrm{CO}_{2}$ emissions throughout the seasons, and higher emissions were observed in the dense urban center than in the moderately urban area. The seasonal variations in SAC exhibited two distinct peaks during the summer and winter periods.

The seasonal variations in the daily $\mathrm{CO}_{2}$ flux were dependent on the daily mean air temperature and exhibited different patterns in different landscapes (Fig. 7). For the urban site of $\mathrm{SAC}, \mathrm{CO}_{2}$ emissions increased as temperatures decreased $\left(0.46-0.27 \mathrm{~g} \mathrm{C} \mathrm{m}^{-2} \mathrm{~d}^{-1}{ }^{\circ} \mathrm{C}^{-1} ; p<0.1\right)$ when the mean daily temperature was less than $10^{\circ} \mathrm{C}$. Higher $\mathrm{CO}_{2}$ emissions were also observed at higher temperatures in SAC. An increase in $\mathrm{CO}_{2}$ emissions at higher temperatures tended 

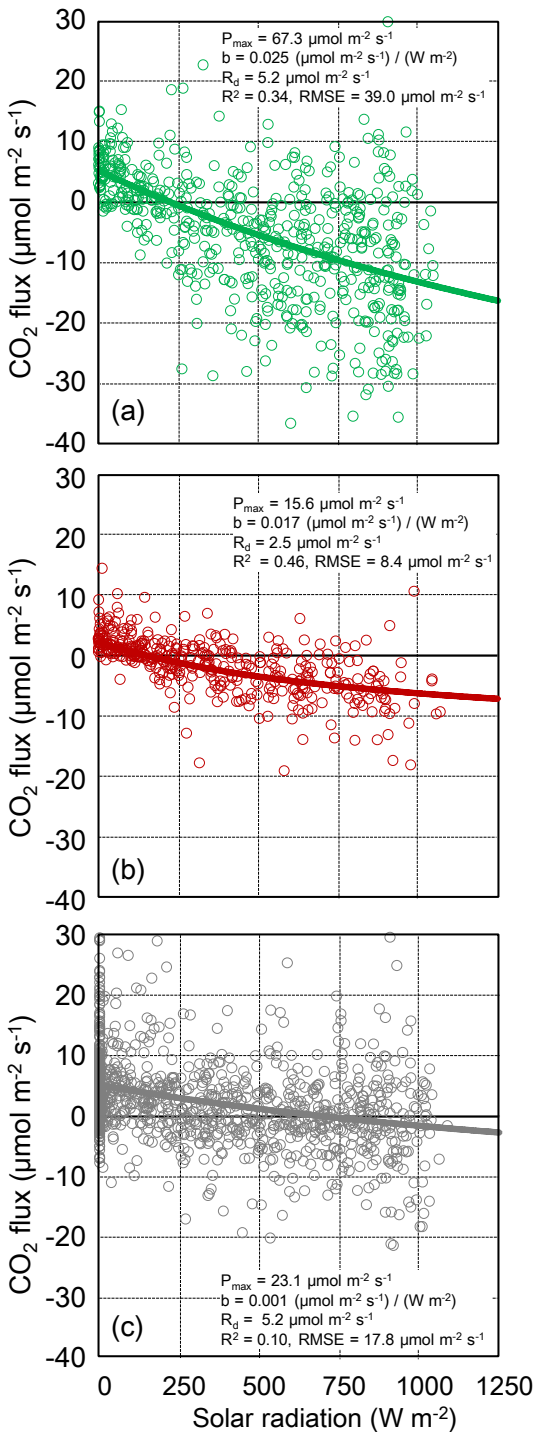

Figure 5. Relationships between the $\mathrm{CO}_{2}$ flux and solar radiation measured at (a) the urban park in IZM, (b) the rural area in IZM, and (c) OPU sites during the period from July to September 2015.

to also be observed at OPU ( $p=0.26)$. Gas consumption by university buildings within a footprint of OPU was consistent with the two seasonal peaks revealing higher consumption in the summer and winter months (Fig. A3). In the urban park and rural area, $\mathrm{CO}_{2}$ emissions decreased as temperatures increased above $15^{\circ} \mathrm{C}$ : $-0.27 \mathrm{~g} \mathrm{C} \mathrm{m}^{-2} \mathrm{~d}^{-1}{ }^{\circ} \mathrm{C}^{-1}$ for the urban park $(p<0.01)$ and $-0.13 \mathrm{~g} \mathrm{C} \mathrm{m}^{-2} \mathrm{~d}^{-1}{ }^{\circ} \mathrm{C}^{-1}$ for the rural area $(p<0.01)$ when the mean air temperatures were greater than $15^{\circ} \mathrm{C}$ (Fig. 7).

Gross photosynthetic fluxes were greater in the summer months than in the winter months (Fig. 6). Surprisingly, the gross photosynthetic fluxes in the urban park and OPU were comparable, probably due to the contributions of trees around the university and from the kofun at OPU.

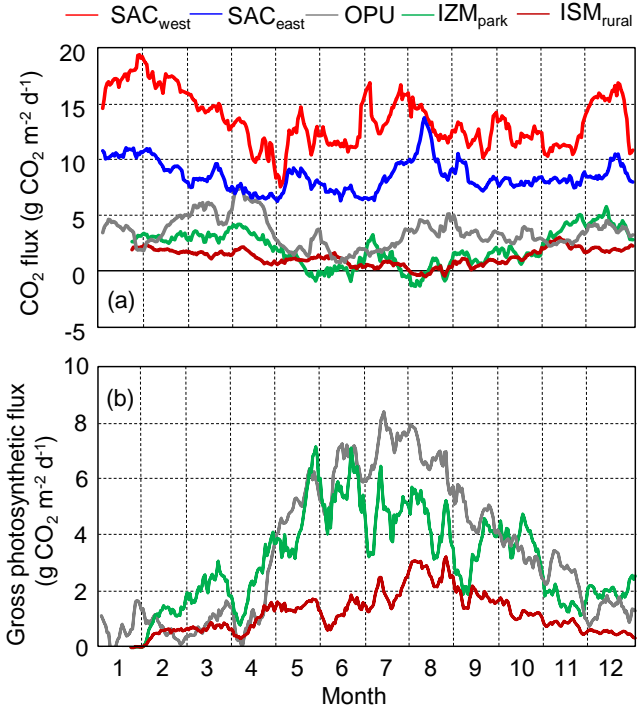

Figure 6. Seasonal variations in the daily mean (a) $\mathrm{CO}_{2}$ fluxes and (b) the gross photosynthetic flux in 2015, shown as 7-day running means.

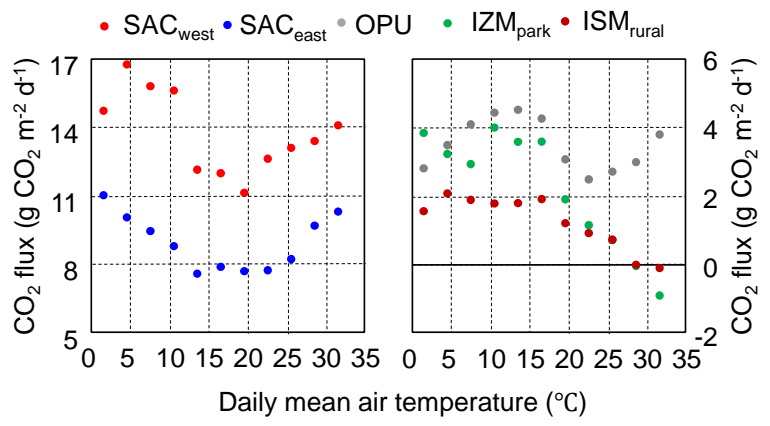

Figure 7. Relationship between the daily mean air temperature and the daily mean $\mathrm{CO}_{2}$ flux; $\mathrm{CO}_{2}$ flux data were binned at $3{ }^{\circ} \mathrm{C}$ intervals.

The gross photosynthetic fluxes for the rural area were approximately half of those for the urban park and OPU. The gross photosynthetic fluxes for the three sites increased as air temperatures increased to more than $20^{\circ} \mathrm{C}$ at 0.15 $0.38 \mathrm{~g} \mathrm{C} \mathrm{m}^{-2} \mathrm{~d}^{-1}{ }^{\circ} \mathrm{C}^{-1}(p<0.01)$.

\subsection{Weekly variations}

Among the five landscapes, distinct weekly cycles of $\mathrm{CO}_{2}$ emissions were only observed at the west SAC and OPU sites (Fig. 8). On average, $\mathrm{CO}_{2}$ emissions on weekdays were approximately $50 \%$ greater than emissions on weekends and holidays $(p<0.01)$ at the west SAC and OPU sites, even though the weekday $\mathrm{CO}_{2}$ flux at the east $\mathrm{SAC}$ was $10 \%$ higher than the fluxes on holidays $(p<0.01)$. The greater emissions on weekdays were consistently observed throughout all seasons, and were consistent with the traffic counts 


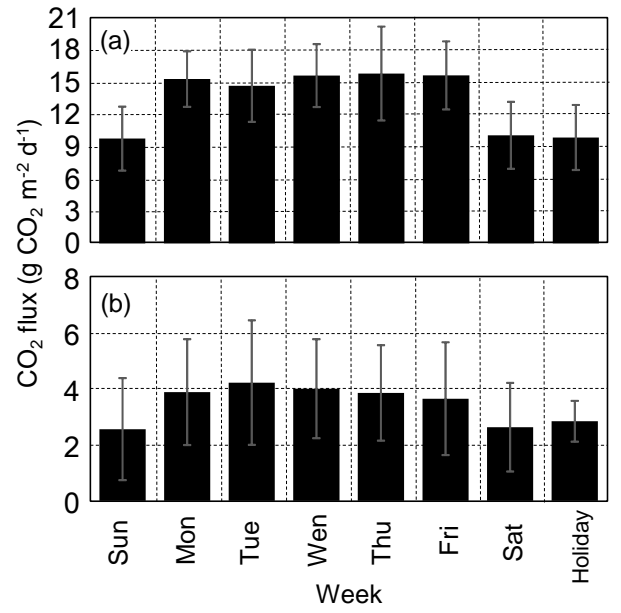

Figure 8. Averaged daily $\mathrm{CO}_{2}$ flux for each day of the week in 2015 for (a) SAC west and (b) OPU; fluxes for holidays were averaged separately. Vertical lines represent standard deviation.

from the highway exits, where traffic was approximately $23 \%$ higher on weekdays than on weekends and holidays (Fig. 4b).

\subsection{Annual $\mathrm{CO}_{2}$ balance and its spatial variations}

All urban landscapes measured in this study acted as a net source of $\mathrm{CO}_{2}$ emissions on an annual timescale (Fig. 9; Table 2). The strength of the annual $\mathrm{CO}_{2}$ emissions was negatively correlated with the green fraction $\left(R^{2}=0.96\right.$; $p<0.01)$; areas with a smaller green fraction had higher annual $\mathrm{CO}_{2}$ emissions. The annual $\mathrm{CO}_{2}$ emissions estimated in this study were lower than those examined using a global synthesis by Nordbo et al. (2012) (Fig. 9).

Based on the significant relationship between the green fraction and the annual $\mathrm{CO}_{2}$ flux, the annual $\mathrm{CO}_{2}$ fluxes were upscaled to the city scale (Fig. 10). Because the green fraction of Sakai was low in the north and high in the south (Fig. 10a), annual $\mathrm{CO}_{2}$ emissions were greater in the north than the south (Fig. 10b). The annual $\mathrm{CO}_{2}$ fluxes from the entire city were $3.3 \mathrm{~kg} \mathrm{C} \mathrm{m}^{-2} \mathrm{yr}^{-1}$, which corresponds to $0.5 \mathrm{Tg} \mathrm{Cyr}^{-1}$ or $1.8 \mathrm{MtCO}_{2} \mathrm{yr}^{-1}$ based on the area of the city $\left(149.81 \mathrm{~km}^{2}\right)$. The estimated emissions were lower than an inventory-based estimate published by the government from 2000 to $2012\left(8.0 \pm 0.6 \mathrm{MtCO}_{2} \mathrm{yr}^{-1}\right)$.

\section{Discussion}

Annual $\mathrm{CO}_{2}$ emissions from Sakai City were in the range of those measured in other studies, but they tended to be at the lower end of the range (Fig. 9). For the same fraction of green area (in this case, the green fraction was less than $20 \%$ ), urban emissions ranged from 4 to $18 \mathrm{~kg} \mathrm{C} \mathrm{m}^{-2} \mathrm{yr}^{-1}$ for other cities (Nordbo et al., 2012; Velasco and Roth,

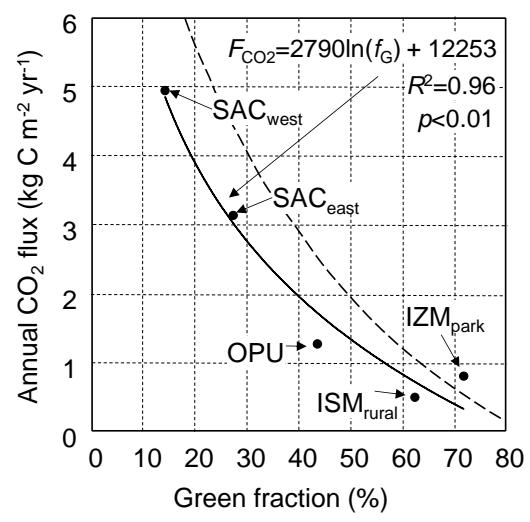

Figure 9. Relationship between the annual $\mathrm{CO}_{2}$ flux $\left(F_{\mathrm{CO}_{2}}\right)$ and the green fraction $\left(f_{\mathrm{G}}\right)$. The solid line represents a regression based on our flux data for Sakai, and the dashed line represents a relationship based on a global synthesis (Nordbo et al., 2012).

Table 2. Annual $\mathrm{CO}_{2}$ fluxes from the eddy covariance measurements and the upscaled city-scale flux.

\begin{tabular}{lr}
\hline Site & $\begin{array}{r}\mathrm{CO}_{2} \text { flux } \\
\mathrm{gC}^{-2} \mathrm{yr}^{-1}\end{array}$ \\
\hline SAC west & 4948 \\
SAC east & 3134 \\
OPU & 1270 \\
IZM park & 802 \\
IZM rural & 495 \\
Upscale & 3325 \\
\hline
\end{tabular}

2010). $\mathrm{CO}_{2}$ emission in our city was lower than that measured in urban centers: a dense urban built-up area in London (12.7 $\mathrm{kg} \mathrm{C} \mathrm{m}^{-2} \mathrm{yr}^{-1}$; Ward et al., 2015), the historical city center in Florence $\left(8.3 \mathrm{~kg} \mathrm{C} \mathrm{m}^{-2} \mathrm{yr}^{-1}\right.$; Gioli et al., 2012), and a residential area of south-central Vancouver $\left(6.7 \mathrm{~kg} \mathrm{C} \mathrm{m}^{-2} \mathrm{yr}^{-1}\right.$; Christen et al., 2011). The annual emissions in our city were also lower than previous cities that had a similar population density; there were only two cities whose populations were higher than that in our city, but the annual emissions in our city were seventh in the global synthesis (Fig. 12b in Ward et al., 2015). The low $\mathrm{CO}_{2}$ emissions rate in Sakai City was evident in the daytime peaks during the winter months (Fig. 4), compared with a dense urban built-up area in London (e.g., more than $50 \mu \mathrm{mol} \mathrm{m}{ }^{-2} \mathrm{~s}^{-1}$; Ward et al., 2015) and a low built-up area in Beijing $\left(30 \mu \mathrm{mol} \mathrm{m}{ }^{-2} \mathrm{~s}^{-1}\right.$; Liu et al., 2012). Warmer winter temperatures (Fig. 2a) may contribute to lower emissions as a result of reduced building heating and thus lower annual emissions in Sakai City compared with other northern cities. The annual emissions rate in our urban center was comparable to that of the densely populated residential areas in Yoyogi, Tokyo (4.3 $\mathrm{kg} \mathrm{C} \mathrm{m}^{-2} \mathrm{yr}^{-1}$; Hirano et al., 2015), and 

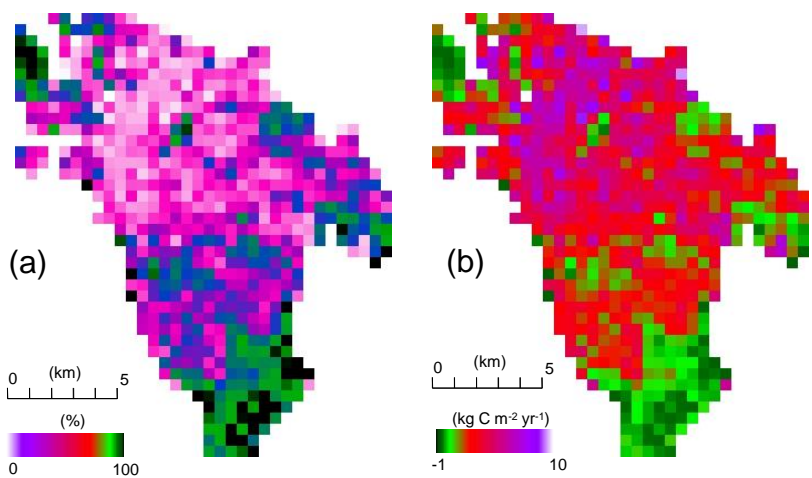

Figure 10. Spatial distributions of (a) the green fraction and (b) the upscaled net $\mathrm{CO}_{2}$ flux in Sakai City. The green fraction was calculated at a $500 \mathrm{~m}$ spatial resolution based on an inventory of green spaces.

Kugahara, Tokyo (3.4 $\mathrm{kg} \mathrm{C} \mathrm{m}^{-2} \mathrm{yr}^{-1}$; Moriwaki and Kanda, 2004).

The sensitivity of the $\mathrm{CO}_{2}$ emissions to cold temperatures was comparable to that described in the previous studies (Bergeron and Strachan, 2011; Liu et al., 2012; Pawlak et al., 2011). The effect of building heating has often been estimated as a slope between air temperature and the $\mathrm{CO}_{2}$ emissions rate: $-2.02 \mathrm{~g} \mathrm{C} \mathrm{m}^{-2} \mathrm{~d}^{-1}{ }^{\circ} \mathrm{C}^{-1}$ in London (Ward et al., 2015), $-0.21 \mathrm{~g} \mathrm{C} \mathrm{m}^{-2} \mathrm{~d}^{-1}{ }^{\circ} \mathrm{C}^{-1}$ in Łódź (Pawlak et al., 2011), and $-0.35 \mathrm{~g} \mathrm{C} \mathrm{m}^{-2} \mathrm{~d}^{-1}{ }^{\circ} \mathrm{C}^{-1}$ in Beijing (Liu et al., 2012). These values are comparable to those obtained in our city: $-0.37 \mathrm{~g} \mathrm{C} \mathrm{m}^{-2} \mathrm{~d}^{-1}{ }^{\circ} \mathrm{C}^{-1}$ for all SAC $(p=0.03)$ and $-0.27 \mathrm{~g} \mathrm{C} \mathrm{m}^{-2} \mathrm{~d}^{-1}{ }^{\circ} \mathrm{C}^{-1}$ for east $\operatorname{SAC}(p<0.01)$ when mean air temperatures were less than $15^{\circ} \mathrm{C}$ (Fig. 7), although the correlation for west SAC was insignificant. No sensitivities to cold temperatures were found in the urban park (west IZM), rural area (east IZM), or residential area (OPU), which could be due to the mixed effects of biological and anthropogenic signals.

$\mathrm{CO}_{2}$ emissions in urban landscapes (SAC and OPU) also increased as temperatures increased in the summer months (Fig. 7): $0.22 \mathrm{~g} \mathrm{C} \mathrm{m}^{-2} \mathrm{~d}^{-1}{ }^{\circ} \mathrm{C}^{-1}$ in west $\mathrm{SAC}(p=$ $0.01), 0.24 \mathrm{~g} \mathrm{C} \mathrm{m}^{-2} \mathrm{~d}^{-1}{ }^{\circ} \mathrm{C}^{-1}$ in east SAC $(p=0.02)$, and $0.13 \mathrm{~g} \mathrm{C} \mathrm{m}^{-2} \mathrm{~d}^{-1}{ }^{\circ} \mathrm{C}^{-1}$ in OPU $(p=0.26)$. The high daytime $\mathrm{CO}_{2}$ emissions were also examined on sunny days when the daytime air temperature was higher than rainy/cloudy days (Fig. A2). Since traffic did not show a clear seasonal variation (Fig. 4b), the reason for this increase is unclear, but one possibility is the contribution of emissions from gaspowered air conditioners (Fig. A3). The prevalence rate of gas-powered air conditioners is approximately $20 \%$ in nonresidential buildings, based on an assessment by the Japan Gas Association. The water vapor flux in the summer months also significantly increased above a mean daily air temperature of $17^{\circ} \mathrm{C}$ (T. Ando, unpublished data), suggesting gas consumption by air conditioners. Kanda et al. (1997) also measured the high water vapor flux in the summer at an ur- ban center, Tokyo, and suggested that gas consumption associated with cooling towers was responsible. In contrast to residences, tall buildings often use gas-based air conditioners, including the Sakai city office and buildings at OPU; especially after the Fukushima nuclear disaster in 2011, nuclear power plants that service the study area are not in operation. Consequently, gas-based air conditioners increased (Agency for Natural Resources and Energy, 2015). A weaker dependence in OPU probably occurred because emissions from gas-powered air conditioners from the university building (Fig. A3) were negated by an increase in biological uptake (Fig. 6b). The sensitivity of gross photosynthetic fluxes to warming temperatures was $0.38 \mathrm{~g} \mathrm{C} \mathrm{m}^{-2} \mathrm{~d}^{-1}{ }^{\circ} \mathrm{C}^{-1}$ in OPU $(p<0.01)$.

Weekly cycles of $\mathrm{CO}_{2}$ emissions were only observed at urban sites (Fig. 8), representing the strength of human activities. Previous urban $\mathrm{CO}_{2}$ flux studies have reported that major contributors to anthropogenic emissions were vehicle emissions and gas consumption (Gioli et al., 2012; Hirano et al., 2015; Velasco et al., 2005; Ward et al., 2013). Velasco and Roth (2010) indicated that weekly cycles were primarily related to vehicle emissions. The traffic count was high on weekdays at SAC (Fig. 4b), and business offices, including the university, are often more active on weekdays than on weekends and holidays. In contrast, there was no clear weekly cycle in the urban park and the rural area. Large differences between weekdays and holidays in west SAC and OPU suggest greater contributions of emissions from vehicles and business offices compared with other landscapes. This underscores the importance of temporal variations in $\mathrm{CO}_{2}$ emissions by land use.

The urban park acted as a net annual $\mathrm{CO}_{2}$ source despite the abundant vegetation. Several factors explain the annual emissions from the urban park. First, the urban park frequently suffered from various management activities, such as harvesting and weeding. Such frequent disturbances could decrease the sink and increase source (Gough et al., 2007; Latty et al., 2004). A warmer climate in the urban area may induce higher respiration (Awal et al., 2010). A limited footprint might influence $\mathrm{CO}_{2}$ fluxes arising from emissions from surrounding areas. We re-checked the data selection using stricter criteria according to which we rejected data when $80 \%$ of the flux footprint exceeded the boundary of the urban park, but the results were almost the same. Annual $\mathrm{CO}_{2}$ emissions of $2.4 \mathrm{~kg} \mathrm{C} \mathrm{m}^{-2} \mathrm{yr}^{-1}$ were previously measured at an urban park in Germany (Kordowski and Kuttler, 2010).

Partitioning the flux data measured at a single site with distinct landscapes is a useful approach in urban flux studies. $\mathrm{CO}_{2}$ fluxes in different landscapes measured at a single site showed considerably different behaviors (Figs. 4, 6, 9). The approach was previously used for clarifying variations in fluxes in different landscapes involved single flux measurements (Järvi et al., 2012; Kordowski and Kuttler, 2010; Hirano et al., 2015). The partitioning concurrently contained the limitations in which data availability decreases with par- 
titioning. In the study area, sea-breeze circulation was dominant in the summer months, resulting in a large data gap from certain wind directions (shown in Sects. 2-3). Accumulating long-term data could be useful for filling the data gap.

The green fraction can be useful for upscaling the annual $\mathrm{CO}_{2}$ flux in urban areas (Fig. 9). The applicability of the green fraction was previously reported based on a global synthesis based on eddy covariance measurements in urban areas (Nordbo et al., 2012; Velasco and Roth, 2010; Ward et al., 2015); the green fraction was an index of human activities (Nordbo et al., 2012). The relationship between the annual $\mathrm{CO}_{2}$ flux and the green fraction in Sakai City tended to be lower than the relationship revealed by the global synthesis (Nordbo et al., 2012) (Fig. 9). This difference might indicate that the relationship differs in each city or country. Other environmental variables, such as biomass density (Velasco et al., 2016), might improve the scaling of $\mathrm{CO}_{2}$ fluxes in various cities. Consequently, to quantify the effects of the green fraction on $\mathrm{CO}_{2}$ emissions in various cities, further direct measurements of $\mathrm{CO}_{2}$ fluxes at various urban sites are required.

Upscaled annual $\mathrm{CO}_{2}$ fluxes for the city (Fig. 10) were lower than estimated using the inventory published by the government. According to the inventory, approximately $57 \%$ of $\mathrm{CO}_{2}$ emissions were associated with the industrial sector, but there was no eddy covariance site in the coastal industrial region. Part of the discrepancy occurred because our upscaling estimated the net flux of urban emissions and vegetative uptake, whereas the inventory quantified the emissions. Hirano et al. (1996) estimated that vegetation in Sakai, primarily in southern sectors, absorbed $0.87 \mathrm{MtCO}_{2} \mathrm{yr}^{-1}$ of $\mathrm{CO}_{2}$ based on an inventory-based estimate. Another reason for the discrepancy was that our estimate did not include hot spot emissions, such as power plants and incineration facilities, or non- $\mathrm{CO}_{2}$ gas emissions. Oda and Maksyutov (2011) estimated that approximately half of total annual $\mathrm{CO}_{2}$ emissions were from point sources in most countries. Because our upscaled $\mathrm{CO}_{2}$ flux did not include such point sources, the $\mathrm{CO}_{2}$ emissions from point sources could be more rigorously quantified using the governmental inventory than non-point sources (Oda and Maksyutov, 2011). Thus, the upscaled $\mathrm{CO}_{2}$ flux could be useful as an additional constraint, providing more information regarding $\mathrm{CO}_{2}$ emissions from non-point sources. Because our simple method potentially contained uncertainties associated with a limited number of 1-year eddy covariance sites, and only the consideration of the green fraction, the estimates should be improved with further eddy covariance sites and additional environmental variables in order to explain $\mathrm{CO}_{2}$ fluxes.
The inherent limitations associated with the eddy covariance method at the urban environment must be reduced and quantified in future studies. The measurement height at SAC was more than 10 times higher than the mean building height, although reducing the height was restricted due to sporadic tall buildings. This could induce underestimates of nighttime fluxes (Oke, 2006), and thus the annual emission could be underestimated. $\mathrm{CO}_{2}$ storage within the building was not considered in our study, but it could be important in the late afternoon and early morning (Vogt et al., 2006). In contrast, the measurement height at OPU was within the roughness sublayer (1.2 to 1.7 times the mean building and tree heights), and thus fluxes were influenced by localized nearby fields (Oke, 2006). Separating wind sectors using the footprint analysis may suffer uncertainties when advection was trigged by wind shifts.

\section{Conclusion}

Based on continuous measurements using the eddy covariance method at three different urban sites, the diurnal, weekly, seasonal, and spatial variabilities in the $\mathrm{CO}_{2}$ flux were evaluated in Sakai, Osaka, Japan. The urban center and university sites acted as $\mathrm{CO}_{2}$ sources in all seasons. A clear weekday/holiday cycle of $\mathrm{CO}_{2}$ emissions was observed at those sites. A diurnal pattern in the urban center was correlated with those for traffic count. High emissions were observed in the urban site in both the winter and summer months, although the traffic did not change seasonally, suggesting that changes in gas consumption influenced the seasonal variabilities. The urban park and rural area exhibited $\mathrm{CO}_{2}$ uptake during the summer months, with distinct daytime uptake. Regardless of the green fraction, all landscapes considered in this study acted as an annual $\mathrm{CO}_{2}$ source. The green fraction was a useful index that explained the spatial variability in the annual $\mathrm{CO}_{2}$ fluxes, as suggested in global scale studies (Nordbo et al., 2012; Velasco and Roth, 2010). The relationship based on eddy covariance data within a single city could be useful to evaluate $\mathrm{CO}_{2}$ emissions at the city scale. The network of eddy covariance measurements within a city is useful for characterizing spatial and temporal variations in net $\mathrm{CO}_{2}$ fluxes in urban areas.

\section{Data availability}

Data on this paper are available upon request to the authors. 
Appendix A

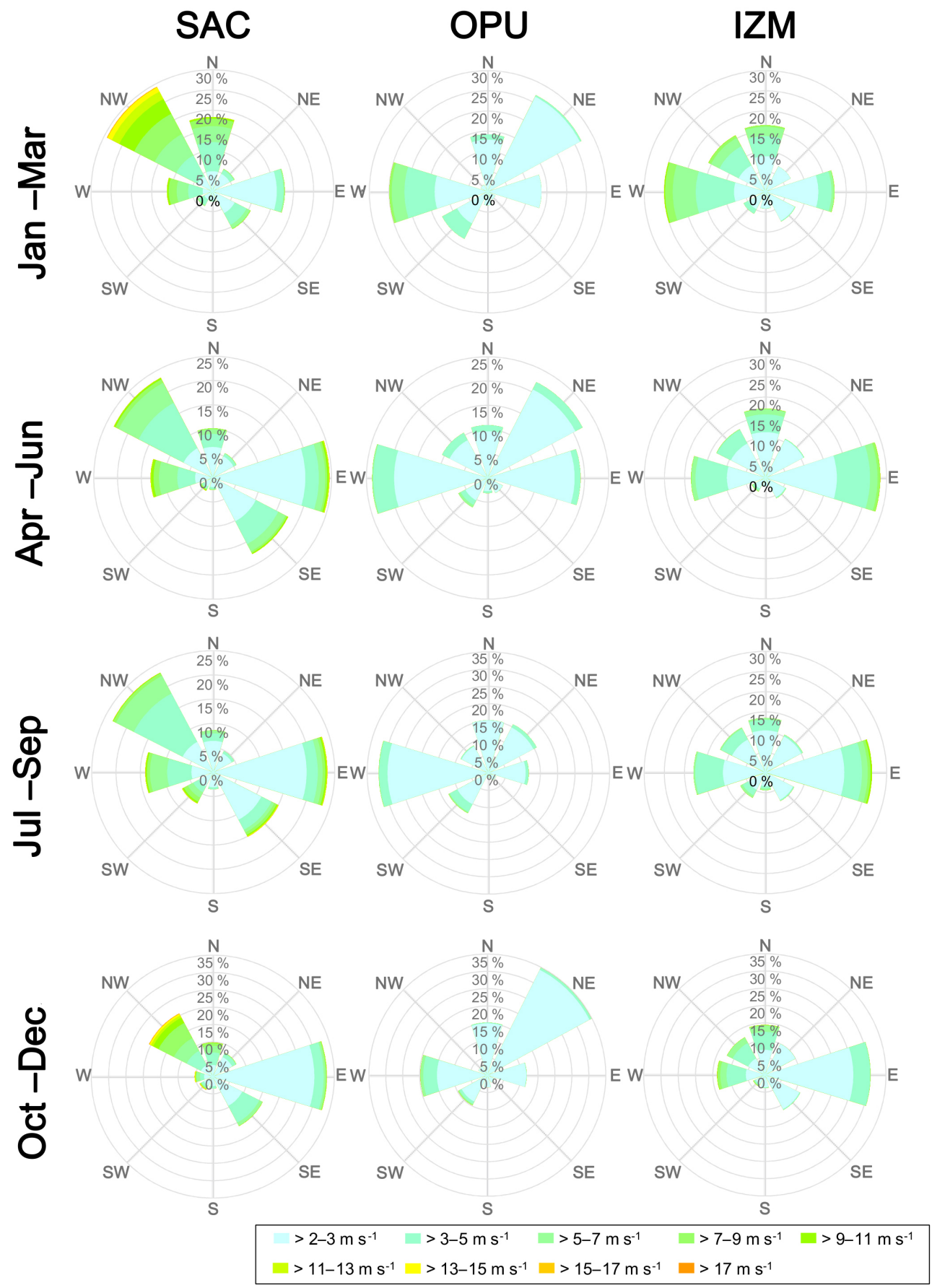

Figure A1. Relative wind frequency distributions at the three sites during the study period in 2015 for each season. Data are binned in $45^{\circ}$ classes. 


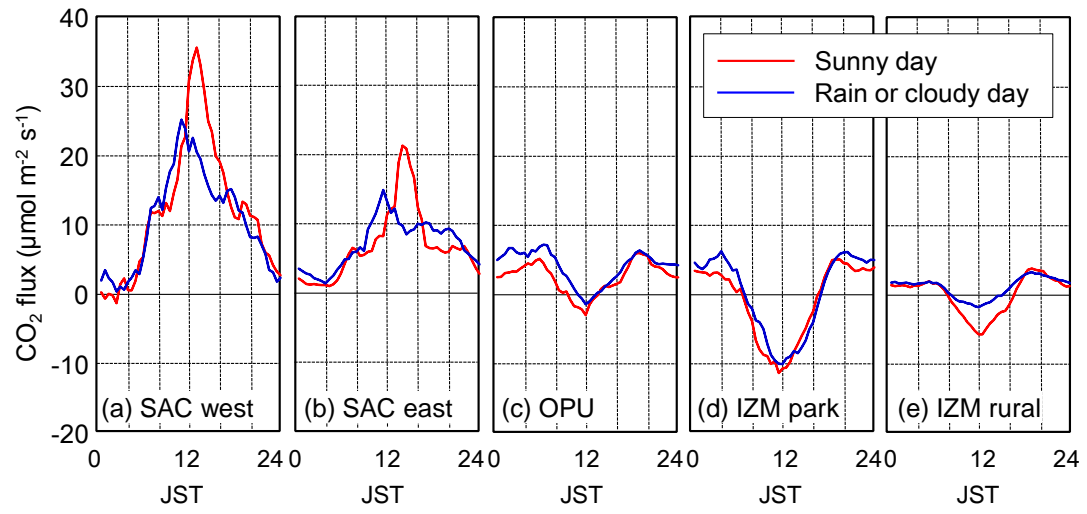

Figure A2. Mean diurnal variations in $\mathrm{CO}_{2}$ fluxes at (a) SAC west, (b) SAC east, (c) OPU, (d) the urban park in IZM, and (e) the rural area in IZM during the period from April to September. The data are shown as the $1.5 \mathrm{~h}$ running means. Sunny days were defined as days when the precipitation was less than $5 \mathrm{~mm} \mathrm{~d}^{-1}$ and the daily sum of solar radiation was greater than $80 \%$ of that expected from solar geometry.

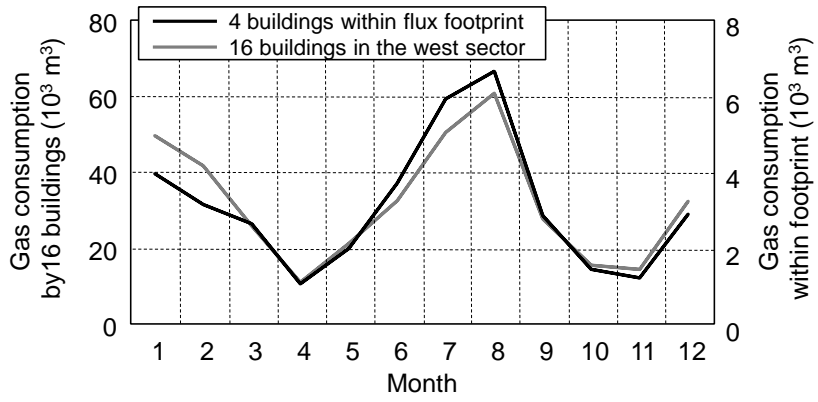

Figure A3. Seasonal variations in monthly gas consumption rates at Osaka Prefecture University for 2015. The data are shown for 16 buildings in the western sector of the university, where flux measurements were conducted, and for four buildings located within the flux footprint. 
Acknowledgements. We thank Hiroyuki Kaga of Osaka Prefecture University for supporting the GIS analysis. We thank the people of Sakai City Office for supporting measurements at SAC. The measurements at IZM were supported by the Sumitomo Foundation (143205). The measurements at SAC were partly supported by Nissei Foundation grants for Environmental Problems, H21. Traffic data regarding the Hanshin Expressway were provided by the Hanshin Expressway Company. Data on gas consumption by Osaka Prefecture University were provided by the university. We thank the two anonymous reviewers for constructive comments.

Edited by: S. S. Gunthe

Reviewed by: two anonymous referees

\section{References}

Agency for Natural Resources and Energy: Current status of gas business, Tokyo, Japan, 36 pp., 2015 (in Japanese).

Awal, M. A., Ohta, T., Matsumoto, K., Toba, T., Daikoku, K., Hattori, S., Hiyama, T., Park, H.: Comparing the carbon sequestration capacity of temperate deciduous forests between urban and rural landscapes in central Japan, Urb. For. Urb. Greening, 9, 261-170, 2010.

Baldocchi, D.: Measuring fluxes of trace gases and energy between ecosystems and the atmosphere - the state and future of the eddy covariance method, Glob. Change Biol., 20, 3600-3609, 2014.

Bergeron, O. and Strachan, I. B.: $\mathrm{CO}_{2}$ sources and sinks in urban and suburban areas of a norther mid-latitude city, Atmos. Environ. 45, 1564-1573, 2011.

Canadell, J. G., Le Quéré, C., Raupach, M. R., Field, C. B., Buitenhuis, E. T., Ciais, P., Conway, T. J., Gillett, N. P., Houghton, R. A., and Marland, G.: Contributions to accelerating atmospheric $\mathrm{CO}_{2}$ growth from economic activities, carbon intensity, and efficiency of natural sinks, P. Natl. Acad. Sci. USA, 104, 1886618870, 2007.

Christen, A., Coops, N. C., Crawford, B. R., Kellett, R., Liss, K. N., Olchovski, I., Tooke, T. R., van der Laan, M., and Voogt, J. A.: Validation of modeled carbon-dioxide emissions from an urban neighborhood with direct eddy-covariance measurements, Atmos. Environ., 45, 6057-6069, 2011.

Coutts, A. M., Beringer, J., and Tapper, N. J.: Characteristics influencing the variability of urban $\mathrm{CO}_{2}$ fluxes in Melbourne, Australia, Atmos. Environ., 41, 51-62, 2007.

Crawford, B., Grimmond, C. S. B., and Christen, A.: Five years of carbon dioxide fluxes measurements in a highly vegetated suburban area, Atmos. Environ., 45, 896-905, 2011.

Foken, T. and Wichura, B.: Tools for quality assessment of surfacebased flux measurements, Agr. Forest Meteorol., 78, 83-105, 1996.

Gioli, B., Toscano, P., Lugato, E., Matese, A., Miglietta, F., Zaldei, A., and Vaccari, F. P.: Methane and carbon dioxide fluxes and source partitioning in urban areas: the case study of Florence, Italy, Environ. Pollut., 164, 125-131, 2012.

Gough, C. M., Vogel, C. S., Harrold, K. H., George, K., and Curtis, P. S.: The legacy of harvest and fire on ecosystem carbon storage in a north temperate forest, Global Change Biol., 13, 1935-1949, 2007.
Grimmond, C. S. B., King, T. S., Cropley, F. D., Nowak, D. J., and Souch, C.: Local-scale fluxes of carbon dioxide in urban environments: methodological challenges and results from Chicago, Environ. Pollut., 116, S243-S254, 2002.

Grimmond, C. S. B., Salmond, J. A., Oke, T. R., Offerle, B., and Lemonsu, A.: Flux and turbulence measurements at a densely built-up site in Marseille: heat, mass (water and carbon dioxide), and momentum, J. Geophys. Res., 109, D24101, doi:10.1029/2004JD004936, 2004.

Hirano, T., Kiyota, M., and Aiga, I.: Vegetation in Sakai City, Osaka, as a sink of air pollutants, Bull. Univ. Osaka Pref., Ser. B, 48, 55-64, 1996.

Hirano, T., Sugawara, H., Murayama, S., and Kondo, H.: Diurnal variation of $\mathrm{CO}_{2}$ flux in an urban area of Tokyo, SOLA, 11, 100103,2015

Järvi, L., Nordbo, A., Junninen, H., Riikonen, A., Moilanen, J., Nikinmaa, E., and Vesala, T.: Seasonal and annual variation of carbon dioxide surface fluxes in Helsinki, Finland, in 2006-2010, Atmos. Chem. Phys., 12, 8475-8489, doi:10.5194/acp-12-84752012, 2012.

Kaimal, J. C. and Finnigan, J. J.: Atmospheric Boundary Layer Flows, 289 pp., Oxford Univ. Press, New York, 1994.

Kanda, M., Takayanagi, Y., Yokoyama, H., and Moriwaki, R.: Field observations of the heat balance in an urban area, J. Japan Soc. Hydrol. Water Resour., 10, 329-336, 1997.

Kochendorfer, J., Meyers, T. P., Frank, J., Massman, W. J., and Heuer, M. W.: How well can we measure the vertical wind speed? Implications for fluxes of energy and mass, Bound.-Lay. Meteorol., 145, 383-398, 2012.

Kordowski, K. and Kuttler, W.: Carbon dioxide fluxes over an urban park area, Atmos. Environ., 44, 2722-2730, 2010.

Kormann, R. and Meixner, F. X.: An analytical footprint model for non-neutral stratification, Bound.-Lay. Meteorol., 99, 207-224, 2000.

Kotthaus, S. and Grimmond, C. S. B.: Identification of micro-scale anthropogenic $\mathrm{CO}_{2}$, heat and moisture sources - Processing eddy covariance fluxes for a dense urban environment, Atmos. Environ., 57, 301-316, 2012.

Latty, E. F., Canham, C. D., and Marks, P. L.: The effects of landuse history on soil properties and nutrient dynamics in northern hardwood forests of the Adriondack Mountains, Ecosystems, 7 , 193-207, 2004.

Liu, H. Z., Feng, J. W., Järvi, L., and Vesala, T.: Four-year (20062009) eddy covariance measurements of $\mathrm{CO}_{2}$ flux over an urban area in Beijing, Atmos. Chem. Phys., 12, 7881-7892, doi:10.5194/acp-12-7881-2012, 2012.

Lloyd, J. and Taylor, J. A.: On the temperature dependence of soil respiration, Funct. Ecol., 8, 315-323, 1994.

MacDonald, R. W., Griffiths, R. F., Hall, D. J.: An improved method for the estimation of surface roughness of obstacle arrays, Atmos. Environ., 32, 1857-1864, 1998.

Massman, W. J.: A simple method for estimating frequency response corrections for eddy covariance systems, Agric. Forest Meteorol., 104, 185-198, 2000

Mills, G.: Cities as agents of global change, Int., J. Climatol., 27 , 1849-1857, 2007.

Moriwaki, R. and Kanda, M.: Seasonal and diurnal fluxes of radiation, heat, water vapor, and carbon dioxide over a suburban area, J. Appl. Meteorol., 43, 1700-1710, 2004. 
Moriwaki, R., Kanda, M., and Nitta, H.: Carbon dioxide build-up within a suburban canopy layer in winter night, Atmos. Environ., 40, 1394-1407, 2006.

Moore, C. J.: Frequency response corrections for eddy correlation systems, Bound.-Lay. Meteorol., 37, 17-35, 1986.

Nakai, T. and Shimoyama, K.: Ultrasonic anemometer angle of attack errors under turbulent conditions, Agr. Forest Meteorol., 162-163, 14-26, 2012.

Nimitz, E., Hargreaves, K. J., McDonald, A. G., Dorsey, J. R., and Fowler, D.: Micrometeorological measurements of the urban heat budget and $\mathrm{CO}_{2}$ emissions on a city scale, Environ. Sci. Technol., 36, 3139-3146, 2002.

Nordbo, A., Järvi, L., Haapanala, S., Wood, C. R., and Vesala, T.: Fraction of natural area as main predictor of net $\mathrm{CO}_{2}$ emissions from cities, Goephys. Res. Lett., 39, L20802, doi:10.1029/2012GL053087, 2012.

Oda, T. and Maksyutov, S.: A very high-resolution $(1 \mathrm{~km} \times 1 \mathrm{~km})$ global fossil fuel $\mathrm{CO}_{2}$ emission inventory derived using a point source database and satellite observations of nighttime lights, Atmos. Chem. Phys., 11, 543-556, doi:10.5194/acp-11-543-2011, 2011.

Oke, T. R.: Initial guidance to obtain representative meteorological observations at urban sites, Instruments and observing methods report No. 81, World Meteorological Organization, 47 pp., 2006.

Pawlak, W., Fortuniak, K., and Siedlecki, M.: Carbon dioxide flux in the center of Łódź, Poland - analysis of a 2-year eddy covariance measurement data set, Int. J. Climatol., 31, 232-243, 2011.

Peters, E. B. and McFadden, J. P.: Continuous measurements of net $\mathrm{CO}_{2}$ exchange by vegetation and soils in a suburban landscape, $\mathrm{J}$. Geophys. Res., 117, G03005, doi:10.1029/2011JG001933, 2012.

Peters, W., Jacobson, A. R., Sweeney, C., Andrews, A. E., Conway, T. J., Masarie, K., Miller, J., Bruhwiler, L. M., Pétron, G., Hirsch, A. I., Worthy, D. E. J., van der Werf, G. R., Randerson, J. T., Wennberg, P. O., Krol, M. C., and Tans, P. P.: An atmospheric perspective on North American carbon dioxide exchange: CarbonTracker, P. Natl. Acad. Sci. USA, 104, 18925-18930, 2007.

Satterthwaite, D.: Cities' contribution to global warming: notes on the allocation of global greenhouse gas emission, Environ. Urban., 20, 539-549, 2008.

Schimel, D. S., House, J. I., Hibbard, K. A., Bousquet, P., Ciais, P., Peylin, P., Braswell, B. H., Apps, M. J., Baker, D., Bondeau, A., Canadell, J., Churkina, G., Cramer, W., Denning, A. S., Field, C. B., Fridlingstein, P., Goodale, C., Heimann, M., Houghton, R. A., Melilo, J. M., Moore III, B., Murdiyarso, D., Noble, I., Pacala, S. W., Prentice, I. C., Raupach, M. R., Rayner, P. J., Scholes, R. J., Steffen, W. L., and Wirth, C.: Recent patterns and mechanisms of carbon exchange by terrestrial ecosystems, Nature, 414, 169$172,2001$.
Ueyama, M., Hirata, R., Mano, M., Hamotani, K., Harazono, Y., Hirano, T., Miyata, A., Takagi, K., and Takahashi, Y.: Influences of various calculation options on heat, water and carbon fluxes determined by open- and closed-path eddy covariance methods, Tellus B, 64, 19048, doi:10.3402/tellusb.v64i0.19048, 2012.

Ueyama, M., Iwata, H., Harazono, Y., Euskirchen, E. S., Oechel, W. C., and Zona, D.: Growing season and spatial variations of carbon fluxes of Arctic and boreal ecosystems in Alaska, Ecol. Appl., 23, 1798-1816, 2013.

Velasco, E. and Roth, M.: Cities as net source of $\mathrm{CO}_{2}$ : review of atmospheric $\mathrm{CO}_{2}$ exchange in urban environments measured by eddy covariance technique, Geography Compass, 4/9, 12381259, 2010.

Velasco, E., Pressley, S., Allwine, E., Westberg, H., and Lamb, B.: Measurements of $\mathrm{CO}_{2}$ fluxes from the Mexico City urban landscape, Atmos. Environ., 39, 7433-7446, 2005.

Velasco, E., Roth, M., Norford, L., and Molina, L. T.: Does urban vegetation enhance carbon sequestration?, Landscape Urban Plan., 148, 99-107, 2016.

Vickers, D. and Mahrt, L.: Quality control and flux sampling problems for tower and aircraft data, J. Atmos. Ocean. Tech., 14, 512 526, 1997.

Vogt, R., Christen, A., Rotach, M. W., Roth, M., and Satyanarayana, A. N. V.: Temporal dynamics of $\mathrm{CO}_{2}$ fluxes and profiles over a Central European city, Theor. Appl. Climatol., 84, 117-126, 2006.

Ward, H. C., Evans, J. G., and Grimmond, C. S. B.: Multi-season eddy covariance observations of energy, water and carbon fluxes over a suburban area in Swindon, UK, Atmos. Chem. Phys., 13, 4645-4666, doi:10.5194/acp-13-4645-2013, 2013.

Ward, H. C., Kotthaus, S., Grimmond, C. S. B., Bjorkegren, A., Wilkinson, M., Morrison, W. T. J., Evans, J. G., Morison, J. I. L., and Iamarino, M.: Effects of urban density on carbon dioxide exchanges: observations of dense urban, suburban and woodland areas of southern England, Environ. Pollut., 198, 189-200, 2015.

Webb, E. K., Pearman, G. I., and Leuning, R.: Correction of flux measurements for density effects due to heat and water vapour transfer, Q. J. Roy. Meteorol. Soc., 106, 85-10, 1980. 